Р. С. Зінчук

\title{
РЕФЛЕКСИ ДАВНІХ ГОЛОСНИХ У СИСТЕМІ СЛОВОЗМІНИ ІМЕННИКІВ ЗАХІДНОПОЛІСЬКИХ І СУМІЖНИХ ГОВІРОК
}

Зінчук Р. С. Рефлекси давніх голосних у системі словозміни іменників західнополіських і суміжних говірок.

На матеріалі західнополіських і суміжних говірок проаналізовано систему іменникової словозміни в аспекті опису виявів у говіркових закінченнях фонетичних закономірностей досліджуваного ареалу, передусім специфіки рефлексації етимологічних голосних. З'ясовано, що флексійну варіантність у субстантивній парадигмі визначають передусім континуанти давнього $\boldsymbol{k}$, а також етимологічних ${ }_{0}$ та *e, якість рефлексації яких, як правило, залежить від наголосу, що також зумовлює просторову поведінку відповідних словоформ.

Ключові слова: говірка, голосні фонеми, рефлекси давніх голосних, іменник, відмінок, флексія.

Зинчук Р.С. Рефлексы древних гласных в системе словоизменения имен существительных в западнополесском и смежных говорах.

На материале западнополесского и смежных говоров проанализирована система словоизменения имен существительных в аспекте анализа проявлений в диалектных окончаниях фонетических закономерностей исследуемого ареала, прежде всего специфики рефлексирования этимологических гласных. Установлено, что вариантность флексии в субстантивной парадигме определяют прежде всего 
континуанты древнего $\mathbf{k}$, а также этимологических $*_{o}$ и $*_{e}$, качество рефлексирования которых, как правило, зависит от ударения, которое также определяет локальное поведение соответствующих словоформ.

Ключевые слова: говор, гласные фонемы, рефлексы древних гласных, имя существительное, падеж, флексия.

Zinchuk R. S. Reflexes of Old Vowels in Noun Word Change System in Western Polisian and Related Patois.

The system of noun word change is analyzed on the material of Western Polisian and related patois to reveal the phonetic regularities in the patois inflection system and the specificity of the reflection processes in etymological vowels in particular. It is ascertained that the inflectional variability in the substantival paradigm is mostly determined by the continuants of the old inflection $\boldsymbol{t}$ and also etymological $* o$ and $* e$ whose reflection quality depends, as a rule, on the non-stressed position conditioning the position of the corresponding word forms.

Key words: patios, vowel phonemes, old vowel reflexes, noun, case, inflection.

Поліський територіально-мовний простір, який уже «у києворуську історичну епоху низкою лінгвальних рис виразно контрастував українському півдню» [19, с. 379], досі зберігає свою самобутність, зокрема в народнорозмовній традиції, акумулюючи як архаїзми, так і явища інноваційного характеру на всіх мовних рівнях. Яскраве свідчення такому твердженню - діалектна словозмінна система в аспекті аналізу виявів у говіркових закінченнях фонетичних закономірностей відповідного ареалу, передусім специфіки рефлексації етимологічних голосних, що вирізняє поліські говірки в українському діалектному континуумі.

Фонетична система поліських говорів у XVI - XVII ст. грунтовно описана В. М. Мойсієнком [19]. Вокальному складу деяких сучасних говірок Полісся присвячено окремі наукові розвідки О. В. Юсікової [25; 26], Т. В. Назарової [21], О. І. Скопненка [23], О. С. Білої [5], Г. О. Козачук [15], Ю. В.Громика [8]. Континуанти давнього $\boldsymbol{z}$ у підляських говірках стали об'єктом уваги Г. Л. Аркушина [2].

Цінний матеріал, що однак потребує грунтовного аналізу, містить досліджуване мовне середовище (територія Волинської та Рівненської областей, а також Брестської області Республіки Білорусь), яке віддзеркалює як давні, так і сучасні процеси становлення діалектних фонетичних та словозмінних норм. Живомовні свідчення поліщуків дають змогу простежити локальну специфіку рефлексації етимологічних голосних та робити висновки про причини флексійної варіантності в окремих відмінкових позиціях субстантивної парадигми західнополіських і суміжних говірок.

Досліджуваний ареал вирізняють, передусім, континуанти

๑ Р. С. Зінчук, 2013. 
давнього $\boldsymbol{b}$ - фонеми, яка в більшості українських говорів та сучасній літературній мові представлена голосним $i$, однак у ретроспективному мовному зрізі, за припущенням дослідників, імовірно, «відзначалася винятковою фонетичною нестійкістю і об'єднувала алофони, які частково співвіснували в одній діалектній системі, а частково вживались лише в певних діалектних зонах» [19, с. 80]. Західнополіські говірки зберігають характерну для північноукраїнського мовного континууму залежність якості рефлексації аналізованої фонеми від наголосу. Водночас, за континуантами давнього $\boldsymbol{k}$ в іменниковій парадигмі можна простежити східну межу західнополіського говору на рівні субстантивної словозміни. За висновками В. М. Мойсієнка, зробленими на основі детального аналізу поліської фонетичної системи, «західнополіський діалект протиставляється середньо- та східнополіським за виявами ғ в обох позиціях по умовній лінії, що проходить дещо на захід від Горині» [19, с. 84].

Так, релевантним для родового відмінка однини іменників жіночого роду 3 м'яким кінцевим приголосним основи в більшості обстежених говірок $є$ наголошене закінчення $-i$ як закономірна для української мови фонетична зміна флексійного $\boldsymbol{k}$ відповідних словоформ субстантивів давніх *-jā-основ, як-от: $\omega m$ зємл $\boldsymbol{k}$. Діалектну специфіку оформлення аналізованої відмінкової позиції в межах досліджуваного ареалу виявляють крайні східні говірки. Відповідно до давньої флексії родового відмінка однини іменників колишніх *-jāоснов згідно з особливостями рефлексації наголошеного $\mathbf{z}$ в окресленій діалектній зоні фіксовані словоформи з такими закінченнями: -'ie:

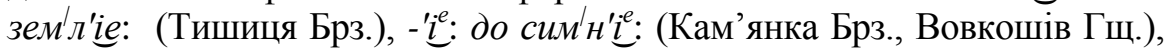
-'e: коло зимл'é (Великий Чермель Дбр., Адамівка Брз.). В іменниках 3 основою на депалаталізований шиплячий приголосний виявлено флексію -ще: б’iз дущще (Великий Мидськ Кс.).

Такі ж рефлекси давнього $\mathbf{z}$ під наголосом фіксовано в закінченнях (давніх чи нових, зумовлених граматичною аналогією) інших відмінкових позицій. Названі форманти визначають діалектну специфіку реалізації місцевого відмінка однини іменників у східній говірковій зоні досліджуваного ареалу, пор.: по во d'ie (Великий

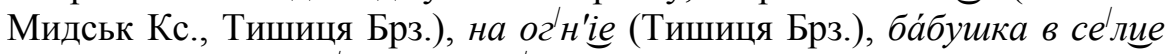

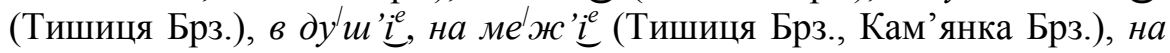
вог̌н'é (Великий Чермель Дбр., Постійне Кс., Борщівка Кс., Адамівка Брз.), в земл'е́ (Борщівка Кс., Адамівка Брз.), пал'ани́щ'i повика́чуйут' на стол'é (Постійне Кс.), вона́ в дру́гом сел'е́ жила́ (Людинь Дбр.), ва́pma ход'íла по сел'é (Чаква Вл.). Фіксації інших дослідників 
свідчать про продовження ареалу таких утворень далі на схід, пор. відповідники в середньополіських говірках: $\check{y}$ ноз'ie $[7$, с. 135], $\check{y}$

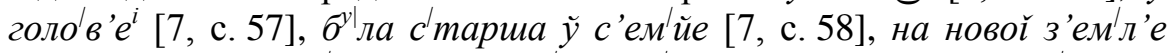

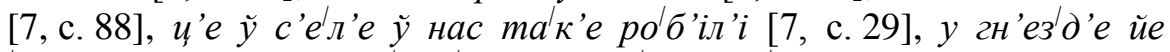
'рамк'i [7, с. 101], на ок'н'е 'верес ум'е'н'е сто 'йіт' [7, с. 108].

Дифтонг iе як характерний рефлекс давньої фонеми $\mathbf{k}$, яка, на думку Ю. В. Шевельова, зазнала дифтонгізації в усіх позиціях, але далі зберегла дифтонгічну вимову тільки під наголосом [24, с. 402], поширений, за спостереженням Г.Л.Аркушина, у підляських говірках, пор. фіксовані дослідником словоформи місцевого відмінка

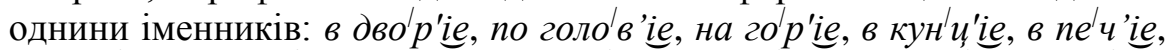

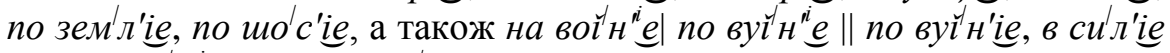

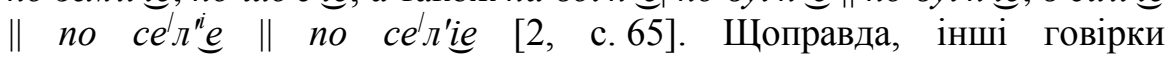
північноукраїнського мовного континууму, хоч і зберігають дифтонгічний вияв давнього қ під наголосом [3 I, к. 3, 5, 7], однак мають помітну тенденцію до поступової уніфікації закінчень місцевого відмінка однини іменників давніх $*-\bar{a}$ - та $*$-о̆-основ через монофтонгізацію дифтонгів.

Форми з наголошеним закінченням -'ie спорадично фіксовані в називному відмінку множини іменників, оформлених за зразком колишніх *-jā-основ, у східній діалектній зоні досліджуваного ареалу, пор.: скри'н'ie mal'수 поро бив (Тишиця Брз.). Більшою частотністю в говірках окресленої діалектної зони позначена однак флексія -'e, пор.: телий'é по два ме́три (Адамівка Брз.), так'í йак кострул'е́ / д'ежк’i // і скрин'е́ були́ (Постійне Кс.), терниц'е́ там стойа́m' (Чаква Вл.).

Діалектну специфіку реалізації ненаголошеного $\boldsymbol{k}$ у західнополіських говірках визначає передусім фонема /и/, пор. фонемний склад звичних для народнорозмовної традиції поліщуків лексем бида, стина, мишок, видро, циловати, спивати і под. (див. також відповідні фіксації Г. Л. Аркушина в підляських говірках [2, с. 66]). Типовим для окресленого ареалу рефлексом давнього $\boldsymbol{k}$ в ненаголошеній позиції прийнято вважати закінчення -u в окремих відмінках субстантивної парадигми. Так, словоформами на - $и$ в більшості говірок досліджуваного ареалу, крім південних та східних, представлений родовий відмінок однини іменників жіночого роду 3 м'яким кінцевим приголосним основи, пор.: суп вари́ели с_квасо́ли, тре ше йако́с' карто́хли на зйему накопа́mu, хо дйв мийлостини просие в, клу́ни булйе так'е́йі / половйена клу́ни так йак пом'і́ст / а да́л'i збйтми тик з глиенни, доп 'іро тико добра́ поба́чили / во́ли / слобо́ди,

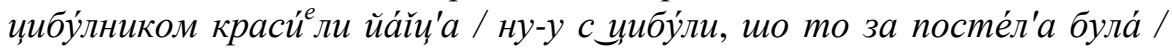
вите́ повтика́ли б с те́йі посте́ли, коло те́йі йа́блуни пу́л'а йо́zо й (C) Р. С. Зінчук, 2013. 
догна́ла, з_вйешни гол'а́к налама́йім / то проку́рим ту ха́mу йакнибу́д'. Закінчення - $u$ родового відмінка однини субстантивів 3 основою на шиплячий, свистячий та сонорний вібрант (пор. 3 народнорозмовної традиції досліджуваних говірок: ка́шу таку́ гу́сту вари́ли і каза́ли шо посл'а қа́ши нима́ па́ши, навб 'і́л'ш то жй то / пшанй цุи ма́ло с'їйали, лед' всп'і́ли до те́йі бу́ри) І.Г. Матвіяс розглядає як імовірний «наслідок впливу відповідних форм іменників *-ā-основ, чому сприяло ствердіння кінцевого приголосного основи» [17, с. 49].

Характерною особливістю, що об’єднує більшість досліджуваних говірок, крім південної діалектної зони, невеликих острівних ареалів на території Рівненщини i Пінщини, $\epsilon$ ненаголошена флексія -и давального та місцевого відмінків однини субстантивів *-̄-основ, а також місцевого відмінка однини іменників 3 основою на $*$-о̆-, пор. відмінкові форми іменників жіночого роду: тре́ба_и було́ д'івции кусо́к по́л'а дийак'е́і прикупйти, музйеии запла́m'am' / maй гра́йе, типе́ра то в костру́л'ųи вару́ / а колй с ' ти́ко чигунйе, пирогй булй на чаре́ни / $i$ на бл'е́си булй / а хл'іб ше памн'ата́йу на липе́си пиклй, л'ітом шчита́і за́вще на пудло́зи спа́ли, в_зимл'а́ничи до́вг 'ї ч 'ес:ид'і́ли, мие то йек горо́х при доро́зи вал'е́лис'а, на бире́зи так і зоста́вс'а вйе сити, в_ка́ждуі ко́мнацу:и по двана́цу:ат' душ бул'і́, без нийа́ко све́тра / в одну́і соро́и:и і бос'ако́м, в_пол'ову́й ла́нщи була́, вбива́ли ск'і́ко йе в_ха́ти симйі / до нац̌ме́нчих дито́к в колиие сци / ж'е́ско аж йак поду́майу. Ареал описуваних словоформ

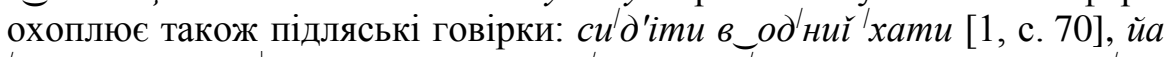

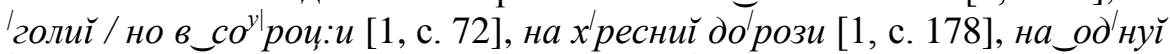

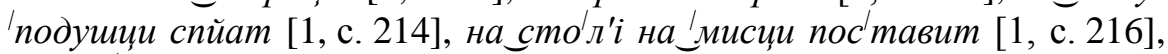
в_my̌́ досліджуваного ареалу на діалектне формотворення аналізованої відмінкової позиції засвідчують і словоформи, фіксовані Ю. В. Громиком у говірці с. Липне Квр., розташованій в ареалі середньополісько-західнополіського пограниччя, пор.: в кумо́ри, на ха́mи, в тазе́ти, в капу́сти, вс'ей брига́ди, пу пра́вди, в це́ркви, на гру́би, в л'а́мпи, на ли́пи, пу мо́ркви, ба́би, в бу́л’би, на маши́ни, в дули́ни, на пири́ни, в пишче́ри, ции́лей шко́ли, в муг'і́ли, на бире́зи, на дуро́зи, пу пудло́зи, в ша́пџฺи, на пуду́сци, тей д’і́винции, в ми́сци, ма́чуси, свикру́си, на стр 'і́си, в ка́ши, на гру́ши, в уде́жи, пу кал'у́жи, в са́жи, на гуну́чи [9, с. 104-105]. Представлену давніми писемними джерелами флексію -и С. П. Бевзенко справедливо вважає наслідком «чисто фонетичних причин» i не простежує в появі аналізованого закінчення вплив відповідних структур давніх *-jā-основ [4, с. 56]. 
I. Г. Матвіяс вважає ймовірними обидва шляхи розвитку флексії - $u$, акцентуючи увагу на ненаголошеній позиції [18, с. 77-78], хоч згодом називає аналізоване закінчення своєрідним місцевим [для поліських говорів. - Р. 3.] рефлексом ненаголошеного $\boldsymbol{k}$ [17, с. 52].

Одним із наслідків характерної для північноукраїнських говорів рефлексації $\mathbf{t}$ у ненаголошеній позиції $\epsilon$ закінчення $-u$ місцевого відмінка однини іменників, оформлених за зразком давніх *-ó-основ [20, с. 57], пор. із західнополіської народнорозмовної традиції: па́сли това́р в л'і́си, то́к'i так'е́йі булиंе в клун'е́х / на тим то́изи й молоти́е ли збиж, висо́ко на ду́би те гниздо́, на заво́ди коло самол'о́туў був, ми за́вще хл'іб на чаре́ни пикли'е, на горо́ди бу́л'бу копа́ла йакра́з, ка́жут' । руса́лк'i в жйети сид'е́m' i л'ака́йуm', хто на вирите́ни / хто на ко́воротку пр'е́ли, мучй ли йуго́ в о́зе $р$ и, в де́реви ти жуки́, за́вше на

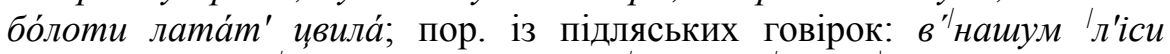
[1, с. 180], на болоти [1, с. 222], ихходил'і по 'тому 'жити [1, с. 270],

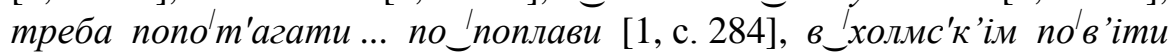
[1, c. 410], jájc'a varýt'f_tom žýty [28, с. 15], із берестейсько-пінських:

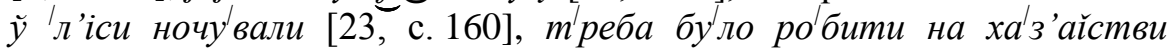
[23, с. 171], я була на хутыры [14, с. 117], молодые роблять в софхозы $[10$, c. 287$]$. Більшу супроти літературної норми частотність уживання флексії $-u$ в місцевому відмінку однини аналізованих іменників засвідчують і словоформи з говірки с. Липне Квр., пор.: в л’і́си, на ду́би, на гуро́ди, в го́руди, на заво́ди, на бе́ризи, в кужу́си, на сло́ни, на присто́ли, на по́вирси, в л'о́си, на по́плави, на пуро́зи, пу муро́зи, на ро́вири, на база́ри, на ватза́ли, в зо́шити, в ко́мини, на пирила́зи, на вб'і́и, на са́мом ве́рси, на гур'і́си, на хо́лоди, в цее́нтри, на ху́тури [9, с. 107], в кр'ісли, на том сло́ви, на було́ти, в с'іни, на кул'іни, в куритти, на вдийа́ли, в ца́рстви, на кул'е́си, на пул'іни, на де́рви, в го́ции, в ку́хри, в жи́ти, на вирт'о́ни, в го́зири, пу хадз'а́йстви [9, с. 108].

Інтегруючий вплив $\mathbf{b}$-закінчень місцевого відмінка однини іменників із твердим кінцевим приголосним основи на словозмінний вияв субстантивів із м'якими основами [20, с. 59] перетинається 3 органічним рефлексом давнього -и колишніх *-јо̆- чи *-̌-основ [4, с. 46; 17, с. 116] у західнополіських словоформах на зразок $в$ коло́d'ази, по н'і́хти, на по́ли, пор. 3 народнорозмовної традиції поліщуків: вже в ко ло́д'ази во ди́ нима́йе, то на руса́лним те́жни вме́рли вихо́дили, зайн'е́в тро́х'i по н'і́хти молотко́м, йака́с' ва́вка на ли́кти, со́нце за́і̆е / а ми ше на по́ли / роботи_ш на_по́ли мо́ре, на с'о́му м’ісци так $i$ впав / то вс'ог̆ ч’ес т'е́шко на се́рции посл'а його́ сме́рти. 
Відмінкові форми, як-от: на брига́де, в ха́те, в ба́нцее, в коро́бце, на ла́вц̧е, в глади́шие, на ти́ų:е, зрідка фіксовані в говірках східної діалектної зони досліджуваного ареалу, репрезентують ще одну локальну особливість субстантивної парадигми. Ненаголошену флексію -е, на думку І.Г. Матвіяса, можна вважати фонетичним рефлексом давнього ненаголошеного $\mathbf{b}[18$, с. 77]. Т. В. Назарова в поодиноких аналізованих словоформах вбачає передусім вияв «спорадичного вторинного вирівнювання ненаголошених закінчень до наголошених» [20, с. 61].

Менш активно 3 огляду на відмінкову всеосяжність, однак достатньо продуктивно в аспекті розгляду окремої відмінкової позиції відображені в субстантивній словозміні досліджуваного ареалу наслідки еволюції давнього *o в новозакритому складі. Рефлекси аналізованого голосного визначають локальну специфіку реалізації родового відмінка множини іменників в обстежених говірках. Етимологічний $*_{o}$ в закінченні *-oвъ, первісно характерному для

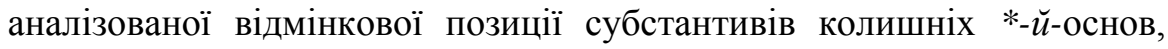
однак уже з XI ст. фіксованому в словоформах іменників з основами на *-o- [4, с. 81], у досліджуваному ареалі реалізований, як правило, у трифонемній системі голосних /i/, /и/, /y/, іррадіацію яких у діалектному просторі визначає наголошена чи ненаголошена позиція та кінцевий приголосний основи (лінгвогеографічне представлення виявів родового відмінка множини іменників, оформлених за зразком давніх *-о̆-, *-јо̆-основ, - кк. 42а, 42б, 42в, 43a, 43б, 44a, 44б, 44в, 45 атласу [11]), пор.: с'ійали і мак / нихто́ тогд'í ни'знав тие х наркома́нув / i ни пили́е сти́ко / ни_бу́ло алкашй ${ }^{i}$ йак типе́р (Заболоття Лбм.).

Закріплене літературною нормою закінчення - ${ }^{\text {()) }}$ ів у наголошеній позиції в більшості західнополіських говірок поширене передусім у родовому відмінку множини субстантивів 3 основою на кінцевий задньоязиковий та фарингальний, в окремих говіркових групах північно-західної, північно-східної діалектних зон та на півдні досліджуваного ареалу фіксоване серед відмінкових форм іменників iз кінцевим губним приголосним основи, значно менш активне при формотворенні аналізованої відмінкової позиції інших субстантивів.

Діалектні вияви родового відмінка множини іменників у говірках обстеженої території позначені особливою продуктивністю наголошеної флексії -ив, як правило, у відмінкових формах іменників 3 основою на передньоязиковий консонант, пор. iз говірок Волинського Полісся: ни було́ вже млини́в тих, ма́ло було́ чигуни́в / тико так’е́ вили'ек'i горшк’é, роби́ла в пани́в і вљжии́в, брати́в було́ 
пйám' i c'ic'm "'s' о́р ште́ри, в нас ни_було́ тут воли́в, ни конй / ничо́zо / все вєкохо́з бра́ли, коло л'іси́в росте́, па́ра бои'уни́в, ни_було́ ти х дохтори́в і нишчó, нихто́ трахтори́в ни ба́чив, в_тих багатири́в позичй ли, а також фіксації дослідників у підляських говірках: пйат' pal $_{\text {зив }}\left[1\right.$, с. 70], берестейсько-пінських говірках: то хах $\left.\right|_{л и}{ }_{\check{y}}$ во ни

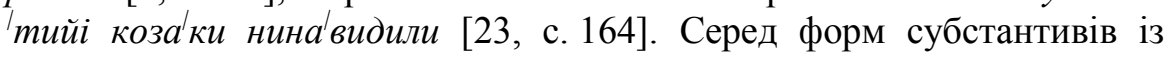
кінцевим губним приголосним основи аналізоване закінчення поширене передусім у говірках центральної діалектної зони обстеженої території, пор.: три́ų:um' снопи́в / то пувк'і́ки зва́лис'а, було́ тиех гриби́в по_л'і́си вс'а́ких, мн'і́го дуби́в у на́шим л'і́си, назбира́йе хву́ру баби́в $i$ визе́ по йа́годи, було́ жаби́в у вод'і́ коли́е с' । munép то і̌ до ха́ти ни раз л'їут'.

Наголошена флексія -ув визначає специфіку родового відмінка множини іменників, оформлених за зразком давніх *-ó-основ, у говірках східної частини досліджуваного ареалу, пор.: купл'а́ли в пану́в боло́то, було́ па́ра штук тих жиду́в, па́ра волу́в, тод'і́ мл'іну́в ни_було́, ше́здис'ат снопу́в у коп'í, бага́щ'ко грибу́в, не_було́ за По́л'шчи в_нас трахтору́в, бага́то хутору́в спали́ли; пор. також фіксації дослідників в окремих середньополіських говірках: ну сто дво руў у наз бу ло [7, с. 99], на вед ро гур $^{\prime}$ куу [7, с. 283].

Більшою продуктивністю в народнорозмовній традиції Західного Полісся позначені словоформи 3 ненаголошеним закінченням -ув у родовому відмінку множини іменників, пор.: $н и$ було́ е́тих сала́тув шо типе́р, а тогдйe докуме́нтув ни було́, шо вже салда́тув побйетих лиж'е́ло / аж стра́шно, горо́дув ма́ла бага́то / а косй ли то ти́ко вручну́ пока́мис' ни було́ ше комба́і̆нвв тиех, мишк'е́ так'е́ на в'іс'ім пу́дув шиелл на збо́же, вучйлас'а до штиро́х кла́сув, бригад'ірув то мно́го було́, двана́и:ит' ме́трув дав ба́т'ко пшеничи за ту кобйлу, ни зна́йу куол'к'i ікта́рув, вс'ого́ два́щ:ат' о́с'ім гри́вн'ікув пе́нцийі получи́ла, так’іх к’е́л'імкув ма́йу в 'іс'ім / i все на́чи, топ'іро вме́не йе́с'и̧'а с'ім ону́кув / а де́с'іт' пре́нукув; пор. також фіксації дослідників у підляських говірках: ка'тол'ікув [1, с. 28], вже 'жадних будинкув ни_було в_нас [1, с. 56], 'maistruf [28, с. 46], vus'imnájc'it' mórguf butó [28, с. 172], pol ĺakuf [28, с. 276], у берестейсько-пінських

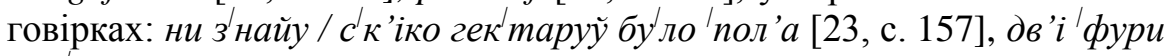
бан дитуу [23, с. 172], нэ було колхозув [10, с. 283].

Ненаголошене закінчення - ") $і в$ простежене в родовому відмінку множини іменників із кінцевим задньоязиковим та свистячим приголосним основи в окремих говіркових групах південної діалектної зони досліджуваного ареалу, значно менш активне при () Р. С. Зінчук, 2013. 
формотворенні аналізованої відмінкової позиції інших субстантивів.

У говірках південної діалектної зони виявлено також словоформи із ненаголошеною флексією -ив, пор.: бага́то типе́p muex наркома́нив / банд'і́тив ра́зних розвило́с'а, тико самол'о́тив ле́тало, йак засй пл'ат' тудй з авто мма́тив / то тико пу́л'і йак дошч, коли́с' ни було́ комба́і̌нив, до трий':ати́ гра́дусив моро́зу було́, по́л'а ма́ли в 'ic'iм ікта́рив, ни зна́йу ск'і́ко там тих ме́трив; пор. фіксації М. М. Корзонюка в західноволинських говірках: куле́сь ни було́ завіссив [16, с. 73], ни́хто і ни ба́чив буклажа́нив [16, с. 77], сім гуро́див - їна́ де́ня [16, с. 106].

Виразну діалектну специфіку у формотворенні родового відмінка множини іменників, оформлених за зразком давніх *-о̆основ, виявляють говірки східної частини обстеженої території, кількісний склад рефлексів етимологічного *-о̆- яких більший, ніж у решті говірок досліджуваного ареалу. Так, наголошену флексійну позицію вирізняють частково монофтонгізовані $-y^{u} b,{ }^{y} \underline{u} в$, пор.: кладе́ш з пен'ку в ого́н', клинка́ми забива́ли з обо́х боку в вуйу дежи́, грибу в в

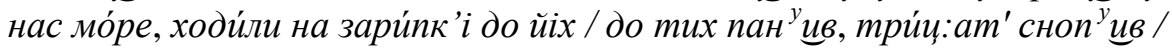
така́ пувкопа́ була́. Фіксовані в окресленій діалектній зоні й словоформи із закінченням -ов, просторова поведінка якого не пов'язана 3 акцентуацією, пор.: ста́ли с хуторо́в гони́m', ма́ти насу́шит' тих грибо́в на и'і́лу зиму, зубо́в нима́ зус'і́м ўже, бурако́в не са'ійали так, було́ па́ру тих бан'ачко́в, ск'і́ко кла́сов пита́йіш / ну

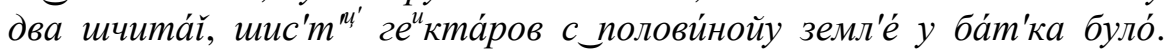
Відмінкові форми на -ов активно вживані в середньополіських

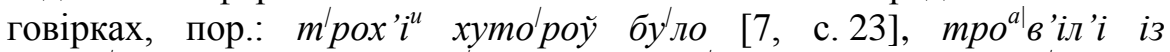

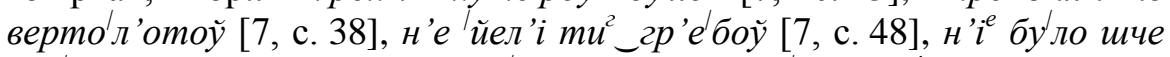
кол госпоў [7, с. 59], да ста г'радусой m'емn' épamyрu ${ }^{i}$ [7, с. 111], по селу ганчароу було [7, с. 250], m рошки ка пусти / а то гу'рочкоў [7, с. 282], 'вос'ем к’ілометрой, сноп'ік колоской [22, с. 33], клопотож, cylc'idow, ol p'ixоw, чоло в'ікош [6, с. 126].

Найдавніші пам'ятки зберігають форми родового відмінка множини іменників колишніх *-јо̆-основ, як-от: вождевъ, дъждевъ, оть плачевъ [4, с.81]. Фіксації подібних відмінкових форм у писемних джерелах пізнішого періоду дають підстави дослідникам стверджувати, що “вже в XV - XVI ст. флексія -овъ (у твердій групі іменників) та ii різновид -евъ (у м’якій групі), -овъ або -евъ (в іменниках на шиплячий приголосний, а також на $-u$ та $-p$ ) цілком витіснили старовинні флексії основ на *-о̌-, *-jǒ-" [12, с. 104]. Розвитком -евъ $\rightarrow-ю в \rightarrow-i в$ [12, с. 104] позначена словозмінна 
система говірок досліджуваного ареалу (рефлексація давнього *e у флексії родового відмінка множини іменників, оформлених за зразком колишніх *-јо̆-основ, може перетинатися 3 аналогійним впливом словоформ із відповідним рефлексом $*_{o}[27$, с. 306]). Закріплене літературною нормою закінчення - ${ }^{\text {()) }}$ в родового відмінка множини субстантивів, оформлених за зразком давніх *-јо̆-основ, фіксоване передусім у говірках південної діалектної зони обстеженої території. Більшість говірок Волинського Полісся виявляють опозицію наголошеного - ") ів та ненаголошеного - ")yв, пор.: а бидова́ли в:уц̌ну́ /

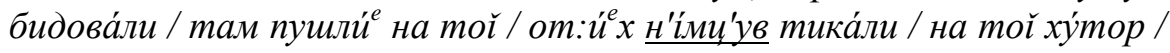
пок'е́нули до́му $i$ все пок'е́нули / там у йідниех нас сид'і́ло ше́стеро там хаз'айів у клу́ни (Журавлине Ст), ко но́пл'і то мо чйлли / ск'іко

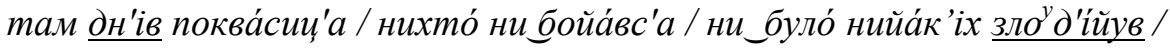
поква́сиц'а дн'iв па́ру / тоуд'í вивол'іка́ли і приво́зили дудо́му (Машів Лбм). У народнорозмовній традиції говірок східної діалектної зони досліджуваного ареалу вживані словоформи 3 наголошеним закінченням - ') $у в$, пор.: позабира́л'i все од_хаз'айу́в у тог̆ колхо́з, нас ви́визли / йак вивозили куркул'у́в, постойі́m дн'ув два три / да_̌̌ осо́хне mог̆ л'он. Словозмінну систему говірок східної діалектної зони вирізняють також відмінкові форми субстантивів із кінцевим свистячим приголосним основи, що пережив депалаталізацію, пор.: с'ім бохуниу́в, ма́ти напече́ с'іх млиниу́в, не було́ тих голуб иу́в йак те пе́р, ку́л'к’i то ста́риув ходи́ло, ше де́вйат' м’іс'ацув там бу́ла, а також пришл'і ми з б’е́жанцов, прогна́л'i е́тих н'е́мцьов, ше па́ру хло́пцฺов було́.

Окремі флексійні варіанти субстантивної парадигми досліджуваного ареалу позначені наслідками розвитку етимологічних $*_{i}$ та $*_{y}$, «спорадичне помішування яких відзначене уже в найдавніших писемних пам'ятках 3 південноруських (українських) теренів» [19, с. 229]. Так, діалектну специфіку орудного відмінка множини іменників у говіркових групах Рівненщини (дубровицькі, суміжні сарненські, володимирецькі й березнівські говірки) та невеликих острівних формаціях на території Волинської області (локачинські, суміжні горохівські, деякі любешівські й турійські говірки) визначає монофтонг [i] після губного в закінченні -ами, пор.: тепе́р все ро́бл'ат машина́м'i, мушчи́ни ко́сам'i коси́л'i, да́же корова́м'і гора́л'i, св 'іти́ли ла́мпам'i, засте́л'ут рад'ужка́м'i вс'а́к'iм'i

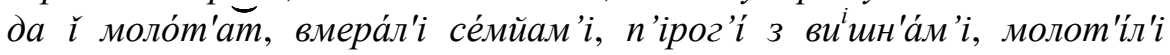
цепа́м'i, серпа́м'i жа́л'i, вола́м’i гора́л'i, куркул'а́м’i зва́л'i, ста́ли сов'е́ти войова́ти з н'і́мйам'i, прача́м'i би́ли те с'і́мйе (у поданих 
прикладах див. також розвиток давнього *i після інших консонантів: гора́л'i, молот'іл'i i под.). Ареал таких словоформ охоплює також підляські говірки: волам'i роб'іла 'навет [1, с. 100], нас кол'іс' нази'вал'і хахлам'i [1, с. 228], моло'т'іл'i / в_клун'i u̧'ilnaм'i [1, с. 314], u_в 'ін кам'i вбе рут [1, с. 388], tak fstúp'iš nohám'i [28, c. 46], s'adájut

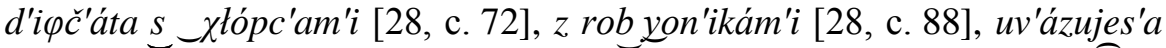
tak'ím'i šnurkám'i [28, c. 186]. šýjes'a rukám'i [28, c. 187], jak vyjižžiel'i stéla / to furmánkam'i [28, c. 204], tým'i ščotkám'i [28, c. 271]. Паралелі відзначено в середньополіських говірках: н'im $\left.\right|_{\kappa a м} i$ пере ложсуво л' $i$

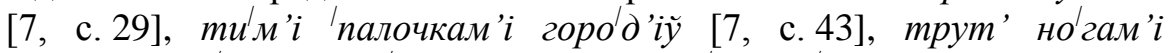

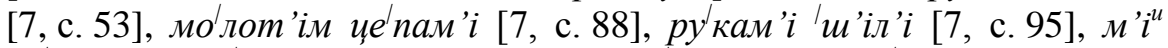
ла' патам' $i$ ко' пайом [7, с. 112], м'i повечер 'ал'i з діе дам'i [7, с. 126],

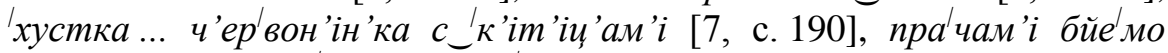
[7, с. 263], тракто рам'і обробл'айемо [7, с. 331].

Етимологічний *y в говірках обстеженого ареалу переважно представлений загальноукраїнським рефлексом [и], за винятком давніх сполук $*_{2 b l}$, *kbl, *xbl, цілковита відсутність написання $b l$ в яких у досліджених В. М. Мойсієнком поліських пам'ятках XVI-XVII ст. дає змогу вченому засвідчити очевидність загальносхіднослов'янської тенденції до зміни ${ }^{*} z b l,{ }^{*} \kappa b l,{ }^{*} x b l$ в $2 i, \kappa i, x i[19$, с. 250], що вже наприкінці XI ст. простежена в південних говорах, з другої пол. ХІІ ст. - у північних i східних говорах [13, с. 248]. Аналізований фонетичний процес визначає специфіку формотворення окремих відмінкових позицій діалектної парадигми іменників. Так, ненаголошене закінчення - $i$ релевантне для родового відмінка однини іменників жіночого роду та називного $\mathrm{i}$ знахідного відмінків множини субстантивів із кінцевим задньоязиковим чи фарингальним приголосним основи більшості досліджуваних говірок, пор. форми Р. в. одн.: ни було́ пудло́z’i ни в_ко́го, в 'іра́ндочка ше така́йа була́ зв 'і́m:и од доро́z’i, бура́к дава́ли / і жсм / i го́сипк'i ск'і́л'ко, нава́рит' ма́ти чигу́н вилйк'ǐ̆ за́терк’i, ни ло́шк'i / ни мийск'i / ни костру́л'к'i / ничо́zо, нима́ типе́p таке́йi о́бувк’i / йак за По́л'ичи була́, дл'а показу́х’i шос' там так'é, тогдй то вмира́ли с_m'ípy / с трасýx 'i / шо то ве́л'ми трасла́, y свикру́х’i ше́стиро дите́й, в 'і́ра то ри́тко булйе з бл'е́х’’; Н., 3. вв. мн.: ну каза́ли руса́вк’i / то в_жсит'і руса́вк’i, мулути́ли / були́ вэсе мулута́рк' $i$ / $i$ в_за́с'ік’ $i$ те збо́же, бра́ли йак'i там ла́х ’ $i$ хо валис' в зимл'а́нках / зимл'а́нк'i так'i ви́копани були́, два ро́к’i пошчи́ ни хожу́ / ни мо́жу і̌mu / нóz'i мл'íŭym'. Наголошена флексійна позиція аналізованих субстантивів представлена словоформами на - ’i передусім у східній та південно-східній діалектних зонах, пор. форми Р. в. одн.: галушк'í вари́ли 3ـмук'í, м’ій ба́т'ко був бе з рук’í, в його́ дочк’í дина́u:ат' дето́к йе, 


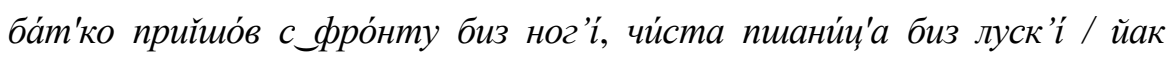
товкачо́м обдире́й'а, з ол'х'i чи з ду́ба кори́ надеру́m'; Н., З. вв. мн.: хоро́ши хустк'í б’їли, нитк'í краси́ли, миск'í / тарилк'i так'ійі, бочк’í були', бул'ба́ни пампушк'i, гладишк'i черепйа́ни, гребйонк'i деревйа́нийі, ти лушпай'í, грушк'í суши́ли, бурак'i так'í иукро́ви, мишк'í були́

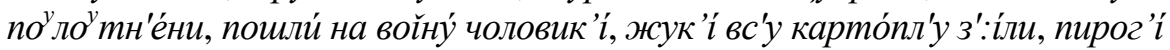
с квасо́л'іüy, плуг'í / бо́рони / все свойе́ було́. Народнорозмовна традиція окремих говірок досліджуваного ареалу засвідчує перетин просторового вияву наголошеного та ненаголошеного - ' $i$ в аналізованих словоформах, пор.: прихо́дит' ба́т'ко / мо лоуди́і / ше два сва́тал'ник’i / а то_̌ три / то

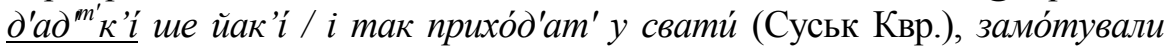
онучка́ли но́z'i / так'í були́ сп 'iй'а́л'ни щнурк'í / во лоск'i назива́лис' (Озеро Квр.), йак ко́ни за́йдут в:ódу / то ти́йі / йак вони / пйа́вк’i опчипл'а́йуu:a $i$ в 'ic'ám по ногáx так'í йак батог'í (Ромашківка Квр.).

Наведений та проаналізований матеріал дає підстави стверджувати, що флексійну варіантність у субстантивній парадигмі західнополіських і суміжних говірок визначають передусім континуанти давнього $\mathbf{k}$, a також етимологічних $*_{o}$ та $*_{e}$, якість рефлексації яких, як правило, залежить від наголосу, що також зумовлює просторову поведінку відповідних словоформ. Наслідки розвитку давніх $*_{i}$ та $* y$ представлені в іменниковій словозміні говірок досліджуваного ареалу спорадично.

\section{Умовні скорочення назв районів}

Волинська область : Квр. - Ківерцівський, Лбм. - Любомльський, Ст. Старовижівський.

Рівненська область : Брз. - Березнівський, Вл. - Володимирецький, Гщ. Гощанський, Дбр. - Дубровицький, Кс. - Костопільський.

\section{Література}

1. Аркушин Г. Л. Голоси з Підляшшя : тексти / Г. Л. Аркушин. - Луцьк : РВВ «Вежа» Волин. держ. ун-ту ім. Лесі Українки, 2007. - 536 с.

2. Аркушин Г. Про статус підляських говірок (межиріччя Володавки і Нареви)/ Г. Аркушин // Gwary północnego Podlasia. - Bielsk Podlaski-Puchły, 2008. - C. 62-68.

3. Атлас української мови : у 3 т. - К. : Наук. думка, 1984-2001.

4. Бевзенко С. П. Історична морфологія української мови (Нариси із словозміни та словотвору) / С. П. Бевзенко. - Ужгород : Закарпатське обл. вид-во, 1960. - 416 с.

5. Біла О.С. Фонетичні особливості північноукраїнських говірок у зв'язку 3 суперсегментними характеристиками / О. С. Біла // Проблеми сучасної ареалогії. К. : Наукова думка, 1994. - С. 144-151.

6. Гладкий П. Говірка села Блиставиці Гостомського району на Київщині / П. Д. Гладкий // Український діялектологічний збірник. - К., 1928. - Кн. 1. - С. 93-141.

7. Говірки Чорнобильської зони : тексти / упоряд. П. Ю. Гриценко. - К. : Довіра, 1996. $-358 \mathrm{c}$.

8. Громик Ю. В. Особливості вокалізму говірок Берестейсько-Пінського Полісся в записах місцевого фолоклору / Ю. В. Громик // Науковий вісник ВДУ ім. Лесі 
Українки. - Луцьк, 2004. - № 6. - С. 109-119.

9. Громик Ю. В. Словозміна іменників у поліській говірці села Липне / Ю. В. Громик // Літопис Волині : всеукр. наук. часопис. - Луцьк : ВНУ Лесі Українки, 2011. - Ч. 10. - С. 104-110.

10. Дыялектны слоўнік Брэстчыны / укл. М. М. Алехновіч та ін. - Мн. : Навука і тэхніка, 1989. - 294 с.

11. Зінчук Р. С. Атлас словозміни іменників у західнополіських говірках / Р. С. Зінчук. - Луцьк : Волин. нац. ун-т ім. Лесі Українки, 2010. - 164 с.

12. Історія української мови. Морфологія / упор. С. П. Самійленко та ін. - К. : Наукова думка, 1978. - 539 с.

13. Історія української мови. Фонетика / відп. ред. В. В. Німчук. - К. : Наукова думка, 1979. - 367 с.

14. Клімчук Ф. Д. Гаворкі Заходняга Палесся. Фанетычны нарыс / Ф. Д. Клімчук. - Мн. : Навука і тэхніка, 1983. - 128 с.

15. Козачук Г. Вокалізм надбузько-поліських говірок / Г. О. Козачук // Проблеми сучасної ареалогії / відп. ред. П. Ю. Гриценко. - К. : Наук. думка, 1994. - С. 260-265.

16. Корзонюк М. М. Матеріали до словника західноволинських говірок / М. М. Корзонюк // Українська діалектна лексика. - К. : Наукова думка, 1987. - С. 62-267.

17. Матвіяс І. Г. Іменник в українській мові / І. Г. Матвіяс. - К. : Рад. школа, 1974. $-184 \mathrm{c}$.

18. Матвіяс I. Г. Називний, родовий, давальний i місцевий відмінки однини іменників І відміни / І. Г. Матвіяс // Українська діалектологія і ономастика : зб. ст. К. : Наукова думка, 1964. - С. 64-79.

19. Мойсієнко В. М. Фонетична система українських поліських говорів у XVI XVII ст. / В. М. Мойсієнко. - Житомир : Вид-во ЖДУ ім. І. Франка, 2006. - 448 с.

20. Назарова Т. В. Іменникові - $\boldsymbol{k}$ - закінчення в північноукраїнських говорах / Т. В. Назарова // Українська діалектологія і ономастика : зб. ст. - К. : Наукова думка, 1964. - C. 50-63.

21. Назарова Т. В. К характеристике украинского волынско-полесского вокализма / Т. В. Назарова // Общеславянский лингвистический атлас : Материали и исследования. 1970. - М. : Наука, 1972. - С. 47-48.

22. Рябець Л. В. Із спостережень над словозміною іменника у середньополіських говірках / Л. В. Рябець // Волинь-Житомирщина: іст.-філол. зб. 3 регіональних проблем. - Житомир, 1998. - № 3. - С. 32-36.

23. Скопненко О. І. Берестейсько-пинські говірки : генеза i сучасний стан (історико-фонетичний нарис) / О. І. Скопненко. - К., 2001. - 174 с.

24. Шевельов Ю. Історична фонологія української мови / Ю. Шевельов. - Х. : Акта, 2002. - 1054 с.

25. Юсікова О. Динаміка вокалізму говірки села Хоробичі Городянського району Чернігівської області / О. Юсікова // Українська мова. - 2007. - № 2. - С. 26-32.

26. Юсікова О. Зі спостережень над системою голосних фонем у поліських говірках / О. Юсікова // Волинь-Житомирщина: іст.-філол. зб. 3 регіональних проблем / ред. В. Мойсієнко, В. Єршов. - Житомир, 2010. - Вип. 22. - С. 310-316.

27. Яворський А. Ю. Українська підляська говірка в поезії Юстини Королько: фонетичний рівень / А. Ю. Яворський // Волинь філологічна: текст і контекст : Лінгвостилістика XXI століття : стан і перспективи : зб. наук. пр. / упор. І. П. Левчук. Луцьк : Східноєвроп. нац. ун-т ім. Лесі Українки, 2014. - Вип. 17. - С. 303-315.

28. Czyżewski F. Polskie i ukraińskie teksty gwarowe ze wschodniej Lubelszczyzny / F. Czyżewski, S. Warchoł. - Rozprawy Slawistyczne. 9. - Lublin : Wydawnictwo UMCS, 1998. $-496 \mathrm{~s}$.

Стаття надійшла до редакції 22.11.2013 р. 